\title{
Analysis on Current Situation and Countermeasure of Domestic Electronic Commerce Logistics in the Internet Age- -Based on Resource Dependence Theory
}

\author{
Jiapeng Zhang ${ }^{1, *}$ and Sijia $\mathrm{Li}^{2}$ \\ 1,2Management Engineering Department, Zhengzhou University, Zhengzhou, China \\ Corresponding Email: author@e-mail.org
}

\begin{abstract}
This paper analyzes the status of electric business logistics in the current Internet era in China, and combines the SWOT analysis with AHP to do the empirical analysis, then puts forward the countermeasure that the electric business logistics resource should be shared based on the resource dependence theory. Through the empirical analysis, it is found that the disadvantages and opportunities of the logistics status are important in the Internet era.The resource sharing strategy based on the resource dependence theory is more scientific. The rational use of Internet technology in electric business logistics industry can achieve "sharing". It is of great significance for its balanced development, intelligent development and optimization and development.
\end{abstract}

\section{Introduction}

In rapid development of information technology society, the ability of mastering Internet technology and data information in enterprises usually determine their future development.

As a productive service industry, the essence of Logistics is to solve the contradiction between time and space. Electrical business logistics is different from the general logistics, it pays attention to timeliness, quality of service and goods information retrospective. Logistics is a large amount of data generated by the industry [1], Internet technology in the vast amount of data found in new knowledge and create new value. Data itself into information, and through the refining of information into a universal law, and ultimately become the ultimate profit.

E-commerce logistics is not only an important part of the implementation of e-commerce and a driving force for development, but also benefits from the depth of Internet innovation integration, which is an important pillar of ecommerce development. E-commerce drives new demands for logistics, with undergoing a transition from the IT era to the era of the DT era, the network will become the era of DT data of new energy [2], "Internet + " lead both opportunities and challenges the data revolution to e-commerce logistics he data revolution .

There is no doubt that the use of Internet technology is the importance of electricity business logistics, logistics services become more accurate through the professionalization of the data processing. Furthermore, electricity logistics problems are to be resolved. Yang Jimei put that China's logistics development lagged behind the emergence of logistics and distribution of e-commerce development but not in-depth; Xie Yurong argues that China's logistics starts late, lacks of support services; Shen Yan claims that other fresh produce of logistics and its distribution costs become higher, the distribution of agricultural products is very difficult to guarantee the quality. Based on the development of electronic business logistics, scholars also studied from different dimensions. SUN Ying and RONG Bing analyze the characteristics of reverse logistics under the e-commerce market, and put forward the suggestion of establishing effective reverse logistics system for the return logistics problem of electronic businessman. Jiang Minglin put forward the logistics cloud of agricultural product innovation and resource integration service collaborative management model; Meng and Guo Chunxia study the supply chain management based on the biopharmaceutical public logistics platform operating mode; Yang Ju-ping puts forward other customer-oriented multi-distribution program of the electricity business logistics "last mile" distribution model .

The research perspective above reflects the specific characteristics of the industrial transformation in the Internet era. Logistics in the era of large data under the external environment has undergone significant changes in value creation and business model has also undergone significant changes in the way[3]. Resource dependence theory refers that the survival of organizations need to draw resources from the surrounding environment, interdependence with the surrounding environment and interaction, which can achieve their goals. Based on the theory of resource dependence, 
this paper puts forward the sharing of logistics resources and the realization of common distribution and common logistics for present situation and existing problems of electric business logistics. As today's logistics enterprises gradually realize their own network, most of the establishment on their own official website promote their businesses. Logistics and distribution design is relatively broad, rich in the form of logistics and distribution. However, in the distribution process, the construction of different logistics network is complex, which causes low efficiency of logistics and distribution of wasting resources very seriously. With the further development of the integration of the data resources, the interdependence and mutual influence between the logistics enterprises and other enterprises in the surrounding environment, the resource allocation has been fully enhanced to a certain extent.

\section{Theoretical basis and status analysis}

From the perspective of resource theory, the survival of the organization absorb resources from the surrounding environment and the interaction with the surrounding environment in order to achieve the purpose, "shared logistics" is a reasonable response to this opportunity to respond to the program.

In this paper, the sharing of logistics industry resources explains from two dimensions, including tangible resource sharing and intangible resource sharing. Physical resources, including logistics and transportation, logistics network, distribution personnel, distribution facilities, the sharing of these tangible resources can avoid duplication in the distribution process of wasting caused by social resources, while avoiding a lot of social funds, the logistics enterprises achieve the sharing of resources. This measure not only can improve the level of service delivery, but also can save excess funds and reduce the degree of road congestion and improve distribution of economic and social benefits. Intangible resources sharing can also be called information sharing. In the current Internet age, information covers a wide range of areas, including business data, buyer data, enterprise distribution of relevant personnel, network, transportation data information. With the logistics enterprise application of Internet technology, network information and data are constantly analyzed and excavated, sellers and logistics companies deal the information effectively, all the logistics resources in the Internet traction under the common services of e-commerce platform are helpful to the seller and the buyer., which reduce the cost and improve the level of service in the field of electrical distribution business.

The SWOT analysis and the AHP analysis method applied in this paper have been widely used in some project analysis and their respective development has been relatively mature. This paper provides a new way to use AHP and SWOT analysis by combining the two methods. The priority of SWOT element is calculated by AHP method, which makes the analysis result more reference, which can provide SWOT method reliability and accuracy. According to the status of the logistics, the advantages and disadvantages of the current logistics enterprises' own environment plus the opportunities and threats brought by the external environment are put forward, and the disadvantages of the logistics enterprises are analyzed and explained emphatically.

\subsection{Strength}

E-commerce logistics with Internet technology achieve the logistics, capital flow, business flow and information flow matching, integration and interactive development.

The development process with Internet technology make a breakthrough in traditional logistics innovation, format, including self-built logistics, third-party logistics, fourth party logistics, logistics and warehousing services surrounding services.At present there are Shunfeng, Shen Tong, the pass, Huitong, tact, rhyme, and other top 20 logistics enterprises, large and involved in the large number of areas. Therefore, the advantages are obvious: the vigorous development of electric power industry to the electricity business logistics market prospect is broad and abundant technical personnel. Only from the development of domestic current logistics enterprises, the industry is huge.

\subsection{Opportunity}

At present, during the transition from IT era to DT era, network data information will become the new energy in DT era [4].

The revolution of data led by Internet has brought opportunities and challenges to E-business logistics. Therefore, the development get the support of national policy and the extensive development and application of Internet technology, as well as the previously mentioned electronic commerce industry flourish.

\subsection{Threat}

With the existing opportunity, electricity and logistics industry are also facing some unavoidable threats, as more than 20 domestic logistics enterprises make the existence of this huge logistics industry increasingly competitive.

Along with competition at the same time, the scale of enterprise infrastructure will change in order to respond to the current competition actively for more development opportunities, causing that the threat of profit reduction.

\subsection{Weakness}


Based on the Internet technology era, in order to acquire better and more scientific countermeasures, this paper lists the existing problems on current status of electronic business logistics industry:

Unbalanced development of electricity logistics, mainly in the festive logistics imbalance and the development of urban and rural electricity logistics imbalance. The first is caused by peak holiday logistics imbalance. The peak of the electricity business holiday shopping, artificial festivals, like the dual pairs of Taobao double eleven and Jingdong 618 , and Spring Festival and other traditional result in holiday shopping spree and logistics congestion. The latter is the imbalance between the development of urban electricity supplier logistics and rural electricity supplier currently. The rural population is low in population density, the volume of electricity trader is not large and the logistics base is relatively backward.

The delivery of electronic business is slow and Internet technology is not intelligent enough [5], Express become "slow delivery" which has a increasingly high probability, actual level of comprehensive intelligence data is to be improved; the abilities of e-commerce enterprises in allocation of goods, coordination and other aspects determine the consumer experience for the logistics speed in a large extent. The current capacity of China's electricity providers in this area ,however, is also clearly to be improved. Now although online goods, businesses and the brand become more, the chance that express changes to "slow delivery" is getting higher. Although, people today in Internet industrial always concentrate on large data, cloud computing and other Internet technology, but in fact the comprehensive level of Internet technology has a long way. Despite China's large population base, broad market, transaction data is very rich, we has not been able to achieve the optimal use of data

Delivery service quality needs to be improved. Distribution services directly affect the end-user experience of online shopping. Poor logistics timeliness and delivery service attitude, and so on, are likely to affect the user's ultimate experience. Distribution service quality sometimes is poor mainly in: delivery timeliness is poor, not according to the agreed time to the goods; Second, the goods damage in the distribution process; Third, delivery staff attitude is poor, these issues have a direct impact on customer experience.

\section{Empirical analysis}

At present, there are twenty major logistics enterprises in China, such as SF, STM, Huitong, Huitong, Yuantong and so on, which is large in size and involves a large number of regions .

So the research is based on SWOT analysis and AHP (Analytic Hierarchy Process), analyzing the current Logistics status qualitatively and quantitatively.

First, SWOT analysis, through the study of the logistics industry of internal and external environment, shows advantages weaknesses, opportunities and threats (Table 1). The factors in Table 1 qualitatively point out actual situation of the electricity supplier logistics, which shows opportunities and strengths brought by the enterprise's own resources and external environment as well as the weakness and the threat posed by the current environment [6].

Table 1. SWOT analysis of resource sharing in logistics.

\begin{tabular}{|c|c|c|c|}
\hline Strength & Opportunity & Weakness & Threat \\
\hline $\begin{array}{c}\text { Market } \\
\text { prospect } \\
\text { S1 }\end{array}$ & $\begin{array}{c}\text { National } \\
\text { policy } \\
\text { support O1 }\end{array}$ & $\begin{array}{c}\text { Slow } \\
\text { delivery } \\
\text { speed W1 }\end{array}$ & $\begin{array}{c}\text { More } \\
\text { intense } \\
\text { competiti } \\
\text { ons T1 }\end{array}$ \\
$\begin{array}{c}\text { Abundan } \\
\mathrm{t}\end{array}$ & $\begin{array}{c}\text { Prosperity } \\
\text { electricity } \\
\text { technical } \\
\text { talent S2 }\end{array}$ & $\begin{array}{c}\text { Susiness O2 } \\
\text { resource } \\
\text { allocation } \\
\text { insufficient } \\
\text { W2 }\end{array}$ & $\begin{array}{c}\text { Infrastru } \\
\text { cture } \\
\text { scale } \\
\text { change } \\
\text { T2 }\end{array}$ \\
\hline $\begin{array}{c}\text { Huge } \\
\text { industry } \\
\text { S3 }\end{array}$ & $\begin{array}{c}\text { Internet } \\
\text { technology } \\
\text { using O3 }\end{array}$ & $\begin{array}{l}\text { Low } \\
\text { service } \\
\text { quality W3 }\end{array}$ & $\begin{array}{c}\text { Profit } \\
\text { reduction } \\
\text { T3 }\end{array}$ \\
\hline \multicolumn{2}{|c|}{} & & \\
\hline
\end{tabular}

The SWOT group of four elements have the two pairs of comparison, and then pairs of SWOT group comparison.In the comparison process, taking into account a number of Internet technology experts and some of the company managers as well as the views of various departments, brainstorm the judgment matrix of each group is obtained (see Table 2, Table 3, Table 4 and Table 5). Then use the maximum eigenvalue method for each SWOT group do a singlelevel sequence, then list the total ranking of the hierarchy and finally calculate the results (see Table 6). 
Table 2. Judgment matrix of strength group.

\begin{tabular}{|c|c|c|c|}
\hline $\begin{array}{c}\text { Strength } \\
\text { group }\end{array}$ & $\mathrm{S} 1$ & $\mathrm{~S} 2$ & $\mathrm{~S} 3$ \\
\hline $\mathrm{S} 1$ & 1 & 1 & $1 / 3$ \\
\hline $\mathrm{S} 2$ & 1 & 1 & $1 / 5$ \\
\hline $\mathrm{S} 3$ & 3 & 5 & 1 \\
\hline
\end{tabular}

Table 3. Judgment matrix of weakness group .

\begin{tabular}{|c|c|c|c|}
\hline $\begin{array}{c}\text { Weaknes } \\
\mathrm{s}\end{array}$ & $\mathrm{W} 1$ & $\mathrm{~W} 2$ & $\mathrm{~W} 3$ \\
\hline $\mathrm{W} 2$ & 1 & $1 / 4$ & 2 \\
\hline $\mathrm{W} 3$ & 4 & 1 & 8 \\
\hline $\mathrm{W} 3$ & $1 / 2$ & $1 / 8$ & 1 \\
\hline
\end{tabular}

Table 4. Judgment matrix of opportunity group .

\begin{tabular}{|c|c|c|c|}
\hline Strength & O1 & O2 & O3 \\
\hline O1 & 1 & 4 & $1 / 3$ \\
\hline O2 & $1 / 4$ & 1 & $1 / 8$ \\
\hline O3 & 3 & 8 & 1 \\
\hline
\end{tabular}

Table 5. Judgment matrix of threat group.

\begin{tabular}{|c|c|c|c|}
\hline Strength & T1 & T2 & T3 \\
\hline T1 & 1 & 5 & 3 \\
\hline T2 & $1 / 5$ & 1 & $1 / 3$ \\
\hline T3 & $1 / 3$ & 3 & 1 \\
\hline
\end{tabular}

We can see from Table 6 that the judgment matrix has satisfactory consistency, so the analysis result is desirable.

At the same time, opportunities and advantages of this project are in a relatively important position.

Through the combination of SWOT and AHP, this paper explains the current situation of electric business logistics with both qualitative and quantitative aspects, gives a more definite and measurable analysis result from all aspects. This result is the basis of coping scientific and systematic strategies in the current domestic situation of the electricity business logistics .

Table 6. Weights table.

\begin{tabular}{|l|l|l|l|l|l|}
\hline SWOT & $\begin{array}{l}\text { Each group } \\
\text { priority }\end{array}$ & SWOT elements & C.R. & $\begin{array}{l}\text { The priority of elements within } \\
\text { each group }\end{array}$ & $\begin{array}{l}\text { The total priority of } \\
\text { the feature }\end{array}$ \\
\hline
\end{tabular}




\begin{tabular}{|c|c|c|c|c|c|}
\hline \multirow{4}{*}{$\mathrm{S}$} & \multirow{4}{*}{0.1485} & S1Market prospect & \multirow{4}{*}{0} & \multirow{4}{*}{$\begin{array}{l}0.1867 \\
0.1577 \\
0.6555\end{array}$} & \multirow{3}{*}{$\begin{array}{l}0.0277 \\
0.0234\end{array}$} \\
\hline & & S2 Abundant technical talent & & & \\
\hline & & & & & \\
\hline & & $\begin{array}{l}\text { S3 Huge } \\
\text { industry }\end{array}$ & & & 0.0973 \\
\hline \multirow{3}{*}{ W } & \multirow{3}{*}{0.4648} & W1 Slow delivery speed & \multirow{3}{*}{0.145} & 0.1818 & 0.0845 \\
\hline & & $\begin{array}{l}\text { W2 Social resource allocation } \\
\text { insufficient }\end{array}$ & & 0.7273 & 0.3380 \\
\hline & & W3 Low service quality & & 0.0910 & 0.0423 \\
\hline \multirow{4}{*}{$\mathrm{O}$} & \multirow{4}{*}{0.2970} & O1 National policy support & \multirow{4}{*}{0.0160} & 0.2572 & 0.0764 \\
\hline & & O2 Prosperity electricity business & & 0.0738 & 0.0983 \\
\hline & & O3 Internet technology using & & & \\
\hline & & & & 0.6690 & 0.1987 \\
\hline \multirow{3}{*}{$\mathrm{T}$} & \multirow{3}{*}{0.0897} & T1 More intense competitions & \multirow{3}{*}{0.0194} & 0.6333 & 0.0568 \\
\hline & & T2:Infrastructure scale change & & 0.1061 & 0.0095 \\
\hline & & T3:Profit reduction & & 0.2604 & 0.0234 \\
\hline
\end{tabular}

\section{Conclusion and significance}

The empirical results show that the inferiority group (0.4648) and the opportunity group $(0.2970)$ have higher priority than the superiority group (0.1485) and the threat group (0.0897), the insufficient social resource allocation (W2) and technology development (O3) have the highest priority among its groups.

The theory of resource dependence emphasizes that under the normal environment, each organization depends on the surrounding environment and interaction between the various organizations, in order to better development.Based on the resource dependence theory and the current status of disadvantages and opportunities of logistics enterprises,this paper puts forward the strategy of resource sharing, which makes the electric business logistics enterprises better seize the opportunity and make up their own disadvantages.

In the era of Internet, logistics enterprises should seize the opportunities brought by external environment and adopt resource sharing strategy to make up their own disadvantages [7].Network of most logistics enterprises is sound, so resource sharing can play a certain role in the development of logistics enterprises. Applying resource sharing strategy to configure society resources, electrical and logistics enterprises can share tangible resource such as the network construction in various regions of the logistics enterprises, the integration of using social resources in the region in a certain extent, which make the sender efficiency improve, buyers and sellers benefit evenly. These all make the sharing of logistics resources play a positive role in promoting as to the development of imbalances. At the same time, the sharing of intangible resources, such as the integration of data and information in the entire logistics industry, run a great help. With the deepening of Internet technology, logistics information is constantly analyzed and excavated. Logistics itself is an industry which can generate large amount of data. It is a new way to professionally process and integrate the data and share information for the whole industry. The sharing of intangible resources or information sharing have a positive role in promoting the intelligent use of electrical logistics

Logistics industry in China started late [7], logistics construction lags behind the rapid development of electricity providers, so the current existence of some real business logistics problems remain unresolved. E-commerce and logistics should promote and coordinate each other to further realize the logistics sharing so that the logistics enterprises are able to complete the work efficiently, allocate social resources rationally and save social capital, these all make that the development of electric business logistics has far-reaching significance in future. 


\section{References}

1. Xu Jiang-ping.Large-scale data power supply to promote the development of logistics. China Market,2014(40):2223.

2. Li Guanyi.Electronic business logistics innovation and traditional logistics transformation under the Internet.Commercial Research,2016(4):187-192.

3. Zhao Jing."Internet +" era of the development of electronic business logistics problems and solutions. Network and informationization. 2015(5):191-211.

4. Wang Zhiling.From the era of large data to see the development of e-commerce logistics and distribution trends.Electronic Commerce .2015(4):27-28.

5. Yang Jimei. Analysis on the Current Situation and Trend of the Development of Electronic Commerce Logistics in China . Logistics Forum, 2014(4):1-2.

6. Hou Ying.E-commerce under the background of the development of China's logistics industry (Master's degree thesis) .2015.

7. Xie Yurong.Electrical and commercial logistics development model and trend analysis.Economic Logistics,2014(11)46-52. 